\title{
Fungicide performance on Fusarium meridionale control, grain yield and grain damage in maize
}

\author{
Maiquiel Diego Fingstag ${ }^{1 *} \oplus$, Ricardo Trezzi Casa ${ }^{1} \oplus$, Amauri Bogo $^{1} \oplus$, Paulo Kuhnem ${ }^{2} \oplus$, Luis Sangoi ${ }^{1} \oplus$, Juliana

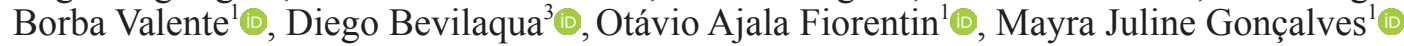

\begin{abstract}
${ }^{1}$ Programa de Pós-Graduação em Produção Vegetal - PPGPV, Universidade do Estado de Santa Catarina - UDESC, Lages, SC, Brasil, CEP 88520000; ${ }^{2}$ Biotrigo Genética, Passo Fundo, RS, Brasil CEP 99050-970; ${ }^{3}$ Aluno de graduação do Curso de Agronomia (UDESC) Lages, SC, Brasil, CEP 88520-000. *Parte da dissertação de mestrado. UDESC, 2017.
\end{abstract}

Endereço para correspondência: Mayra Juline Gonçalves (mayra.juline@hotmail.com)

Data de chegada: 21/03/2018. Aceito para publicação em: 08/02/2019.

$10.1590 / 0100-5405 / 193255$

\section{ABSTRACT}

Fingstag, M.D.; Casa, R.T.; Bogo, A.; Kuhnem, P.; Sangoi, L.; Valente, J.B.; Bevilaqua, D.; Fiorentin, O.A.; Gonçalves, M.J.. Fungicide performance on Fusarium meridionale control, grain yield and grain damage in maize. Summa Phytopathologica, v.45, n.3, p.265-271, 2019.

Gibberella ear rot (GER) in maize, caused by Fusarium graminearum species complex, is a destructive disease in southern Brazil and worldwide. Five field-experiments were conducted to determine fungicide efficacy, grain yield and grain quality (study I), as well as response of increasing rates (study II) on GER control, grain yield (GY) and grain damage (GD) in maize during the 2014/15 and 2015/16 growing seasons. Fungicides were sprayed $48 \mathrm{~h}$ before (preventive action) or $48 \mathrm{~h}$ after (curative action) inoculation of two Fusarium meridionale isolates (PR and MG). Study I consisted in applying nine active ingredients (metconazole, pyraclostrobin, tebuconazole, trifloxystrobin, prothioconazole, thiophanate-methyl, azoxystrobin, cyproconazole and carbendazim) present in eight commercial formulations at two sowing dates. Study II consisted in applying increasing rates of three fungicides evaluated at three sowing dates using only PR isolate. In study I, no differences were observed among fungicides when the variables GER, GY and GD were analyzed together. There were interactions between time of fungicide application and F. meridionale isolates when GER severity and GY were considered. Preventive fungicide application at different sowing dates and the use of MG isolate reduced GER by $11.6 \%$ and increased GY by $5.3 \%$, compared to curative application. In study II, there was a significant interaction between fungicides and application time for GER, GY and GD. Preventive application of trifloxystrobin + prothioconazole $\left(0.15+0.17\right.$ and $\left.0.22+0.26 \mathrm{~L} \mathrm{ha}^{-1}\right)$, pyraclostrobin + metconazole $(0.19+0.12$ and $\left.0.29+0.18 \mathrm{~L} \mathrm{ha}^{-1}\right)$ and carbendazim $\left(2 \mathrm{~L} \mathrm{ha}^{-1}\right)$ reduced GER by 41 and $50 \%$, 47 and $54 \%$, and $54 \%$ at the three sowing dates, respectively. There was an increment of $45.7 \%$ and $46.8 \%$ in GY when trifloxystrobin + prothioconazole $\left(0.15+0.17\right.$ and $\left.0.22+0.26 \mathrm{~L} \mathrm{ha}^{-1}\right)$, respectively, were preventively sprayed at the three sowing dates, compared to the control treatment. Trifloxystrobin + prothiocanazole, pyraclostrobin + metconazole and carbendazim $(1.0$ and $2.0 \mathrm{~L}$ $\mathrm{ha}^{-1}$ ) preventively sprayed at two rates reduced GD incidence by 53.5 and $48.7 \%$, 47.7 and $57.5 \%, 48.1$ and $50.5 \%$, respectively, for each fungicide and rate, and could be incorporated into a disease management program.

Keywords: Zea mays, Fusarium graminearum, chemical control.

\section{RESUMO}

Fingstag, M.D.; Casa, R.T.; Bogo, A.; Kuhnem, P.; Sangoi, L.; Valente, J.B.; Bevilaqua, D.; Fiorentin, O.A.; Gonçalves, M.J.. Desempenho de fungicidas no controle de Fusarium meridionale, produtividade e dano de grãos em milho. Summa Phytopathologica, v.45, n.3, p.265-271, 2019.

A podridão da espiga de giberela (PEG) do milho causada pelo complexo de espécies de Fusarium graminearum é uma doença destrutiva no sul do Brasil e no mundo. Cinco experimentos de campo foram conduzidos para determinar a eficácia de fungicidas, produtividade e qualidade de grãos (estudo I) e resposta do aumento de doses (estudo II) no controle de PEG, rendimento de grãos (RG) e grãos avariados (GA) em milho durante as safras 2014/15 e 2015/16. Os fungicidas foram pulverizados 48 horas antes (ação preventiva) ou 48 horas após (ação curativa) a inoculação de dois isolados de Fusarium meridionale (PR e MG). O estudo I consistiu na aplicação de nove ingredientes ativos (metconazol, piraclostrobina, tebuconazol, trifloxistrobina, protioconazol, tiofanato-metílico, azoxistrobina, ciproconazol e carbendazim) em oito formulações comerciais em duas épocas de semeadura do milho. $\mathrm{O}$ estudo II consistiu em uma aplicação de três fungicidas em doses crescentes e avaliadas em três datas de semeadura com apenas o isolado PR. No estudo I, não foram observadas diferenças entre fungicidas quando as variáveis PEG, RG e GA foram analisadas em conjunto. Houve interações entre o tempo de aplicação dos fungicidas e os isolados de $F$. meridionale quando a severidade de PEG e RG foram consideradas. A aplicação preventiva dos fungicidas em diferentes datas de semeadura e o uso do isolado de MG reduziu a PEG em $11,6 \%$ e aumentou o RG em 5,3\% em comparação a aplicação curativa. No estudo II, houve interação significativa entre fungicidas e tempo de aplicação para GER, RG e GA. A aplicação preventiva de trifloxistrobina + protioconazol $\left(0,15+0,17\right.$ e $\left.0,22+0,26 \mathrm{~L} \mathrm{ha}^{-1}\right)$, piraclostrobina + metconazol $(0,19+0,12 \mathrm{e}$ $\left.0,29+0,18 \mathrm{~L} \mathrm{ha}^{-1}\right)$ e carbendazim $\left(2 \mathrm{~L} \mathrm{ha}^{-1}\right)$ reduziram GER em 41 e $50 \% ; 47$ e $54 \% ; 54 \%$ nas três datas de semeadura, respectivamente. Houve aumento no RG de $45,7 \%$ e $46,8 \%$ quando trifloxistrobina + protioconazol $(0,15+0,17$ e $\left.0,22+0,26 \mathrm{~L} \mathrm{ha}^{-1}\right)$, respectivamente, foi pulverizado preventivamente nas três épocas de semeadura em comparação ao tratamento controle. Trifloxistrobina + protiocanazole, piraclostrobina + metconazole e carbendazim $\left(1,0\right.$ e 2,0 $\left.\mathrm{L} \mathrm{ha}^{-1}\right)$ pulverizados nas duas doses preventivamente reduziram a incidência de GA em 53,5 e $48,7 \% ; 47,7$ e $57,5 \% ; 48,1$ e 50,5\%, respectivamente, para cada fungicida e dose, e podem ser incorporados em um programa de manejo de doenças.

Palavras-chave: Zea mays, Fusarium graminearum, controle químico. 
Gibberella ear rot (GER) in maize (Zea mays L.) is common in southern Brazil; it is a fungal disease of economic importance worldwide, especially due to its potential to reduce grain yield and quality $(1,14)$. GER is caused by Fusarium species complex (FSC) which cause devastating diseases in cereals; additionally, grain size and baking quality are affected, and the harvested grain is contaminated with mycotoxins $(10,15)$. F. graminearum and $F$. meridionale are reported to occur in maize grains in Brazil. A previous study in southern Brazil showed that $F$. meridionale (NIV genotype) can occur as the main species and be more aggressive to maize ears than $F$. graminearum (15-ADON genotype) (11).

In southern Brazil, double-crop system is commonly used for the cultivation of soybean, maize and common bean during the summer and small grain cereals and forage during the winter. No-till system with wheat-maize crop succession is widely implemented in southern Brazil. This system contributes to increased $F$. graminearum inoculum because crop residues remain for longer periods on the ground (12, 23). Fusarium spp. can enter maize ears and grains and their spores can geminate on silks by showing mycelial growth downwards from silks to the grain $(21,25)$. Fusarium produces a pink-to-reddish mold on grains which usually spreads from the tip of the ear downwards or outwards. It is often referred to as pink ear rot or Gibberella ear rot. The diseased grain results in negative grain classification and consequently commercialization (13).

GER management includes best practices by farmers and genotype resistance. However, there is no maize hybrid completely resistant to GER in Brazil (16), and satisfactory control on the field has not been achieved yet. Cultural practices, such as crop rotation and two-year succession of a non-host crop are ineffective (23). Fungicide spraying is one of the most efficient strategies to control Fusarium Head Blight in cereals $(5,24)$. However, there is limited information about the performance of fungicides for chemical control of GER in maize. In addition, fungicide spraying used for leaf diseases $(7,19)$ can improve grain quality $(4,9)$ when not directly applied during flowering with the aim of reducing infection by Fusarium species complex. Application of azoxystrobin + cyproconazole + carbendazim on maize silk-emergence can reduce GER and grain damage, increasing grain yield (1). However, additional studies are necessary to evaluate other active ingredients and rates for GER control. The objective of this study was to evaluate fungicide performance on Fusarium meridionale control, grain yield and grain damage.

\section{MATERIALS AND METHODS}

Five field trials were conducted during 2014/15 (two trials) and $2015 / 16$ (three trials) growing seasons in a no-till area under crop rotation system in Lages County, Santa Catarina State, southern Brazil

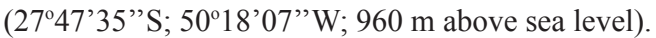

The soil is an aluminic cambisol (Oxisol - class A) with high values of clay and organic matter. It was fertilized with $400 \mathrm{~kg} \mathrm{ha}^{-1} \mathrm{MAP}(5 \%$ $\mathrm{N} ; 20 \% \mathrm{P}_{2} \mathrm{O}_{5}$ and $10 \% \mathrm{KCl}$ ) at sowing. Nitrogen top dressing was performed by using $200 \mathrm{~kg} \mathrm{ha}^{-1}$ urea $(45 \% \mathrm{~N})$, the first half of which was applied at V5 stage and the second half, at V9 stage.

For insect control, $0.15 \mathrm{~L} \mathrm{ha}^{-1}$ lambda-cialotrin + chloranthraniliprole $\left(\right.$ Ampligo $^{\circledR}$ ) was applied 30 days after sowing. Weed control was achieved by using $2 \mathrm{~L} \mathrm{ha}^{-1}$ glyphosate herbicide (Roundup Original ${ }^{\mathbb{}}$ ) 15 days before sowing and $0.4+0.5 \mathrm{~L} \mathrm{ha}^{-1}$ mesotryone + mineral oil $\left(\right.$ Callisto $^{\circledR}+$ Nimbus $\left.^{\circledR}\right) 22$ days after sowing.
The maize hybrid P32R48YH, considered susceptible to GER (17), was sown in the plots. Each subplot unit consisted of four rows (4m-long rows spaced $50 \mathrm{~cm}$ between each other), which received randomized treatments and had a final population of 75.000 plants ha ${ }^{-1}$. Only the two central lines were considered for $F$. meridionale inoculation.

For the experiment of fungicide efficacy, grain yield and grain damage reduction, considering two sowing dates and $F$. meridionale artificial inoculations (described below), harvests were performed on October $22^{\text {nd }}, 2014$, and December $01^{\text {st }}, 2015$; January $13^{\text {th }}, 2015$, and February $16^{\text {th }}, 2016$; and April $09^{\text {th }}, 2015$ and May 01 $1^{\text {st }}, 2016$, respectively. For the experiment of fungicide rates, considering three sowing dates and $F$. meridionale artificial inoculations, harvests were performed on September $14^{\text {th }}, 2014$, November $10^{\text {th }}, 2014$, and December $12^{\text {th }}, 2015$; December $29^{\text {th }}, 2014$, February $01^{\text {st }}, 2015$, and March $03^{\text {rd }}, 2016$; February $16^{\text {th }}, 2016$, and March $15^{\text {th }}, 2015$, April $13^{\text {th }}$, and May $26^{\text {th }}, 2016$, respectively.

Two isolates of $F$. meridionale ( $\mathrm{PR}$ and $\mathrm{MG}$ ) from Uberlândia County, Minas Gerais State (MG-MEMR0004), and Palotina County, Paraná State (PR-MEMR0005), were selected from maize kernel and were previously described to belong to FSC as dominant species of GER in Brazil $(10,16,26)$. The isolates were identified by Polymerase Chain Reaction (PCR) as F. meridionale and genotyped as nivalenol-producer by multilocus genotyping (MLGT) assay. Macroconidia suspension was prepared by growing the isolates on synthetic-nutrient-poor agar (SNA) for 15 days in a $12 \mathrm{~h}$ dark/light cycle. The macroconidia suspensions were filtered with cheesecloth layers and the concentration was adjusted to $2 \times 10^{5}$ macroconidia/mL (21). The silk channel method was adopted and a syringe with an obtuse needle was used to inject $2 \mathrm{~mL}$ macroconidia suspension into the silk channel of the primary ear (22) at 5-7 days after mid-silking (R2 'blister stage'). A mock inoculation with sterile distilled water was included as a negative control.

The fungicides were preventatively sprayed $15 \mathrm{~cm}$ above tassel at $48 \mathrm{~h}$ before inoculation (BI) or curatively at $48 \mathrm{~h}$ after inoculation (AI). An inoculated but no-fungicide (no-spray) treatment was included as control. Fungicide was applied to each treated plot at a volume of 200 $\mathrm{L} \mathrm{ha}^{-1}$ by using a hand-held backpack sprayer which was powered by compressed $\mathrm{CO}_{2}$ and had spray boom with 4 Teejet nozzles (TTJ60110.02 ) spaced $50 \mathrm{~cm}$ apart.

All inoculated ears of each treatment combination, at $22 \%$ grain moisture content, were handpicked and husked, and GER severity score was rated for each ear as the percentage area of symptomatic ear $(17,21)$. The harvested ears were dried at $60^{\circ} \mathrm{C}$ until $13 \%$ humidity was reached; then, they were threshed and weighed. Grain yield was expressed as $\mathrm{kg} \mathrm{ha}^{-1}$. For grain damage, $100 \mathrm{~g}$ samples were randomly assessed in four replicates per plot, according to IN 60/2011 Brazilian Agriculture Ministry Normative (13), as healthy, moldy, fermented and rotten grain.

\section{Study I: Fungicide efficacy, grain yield and grain damage reduction}

Fungicides were assessed in a $2 \times 9 \times 2$ factorial split-plot block design with four replicates. Two application times (preventive and curative), nine fungicides and two $F$. meridionale isolates were randomly allocated to the main plots, subplots and sub-subplot units, respectively. Trade names, active ingredients and fungicide rates are presented in Table 1. The fungicides used in this study were chosen based on the actual recommendation for wheat Fusarium head blight (FHB) or maize foliar disease control. 
Table 1. Summary of fungicides and rates applied 48 hours before or after inoculation at five days after silk emergence in study I and study II.

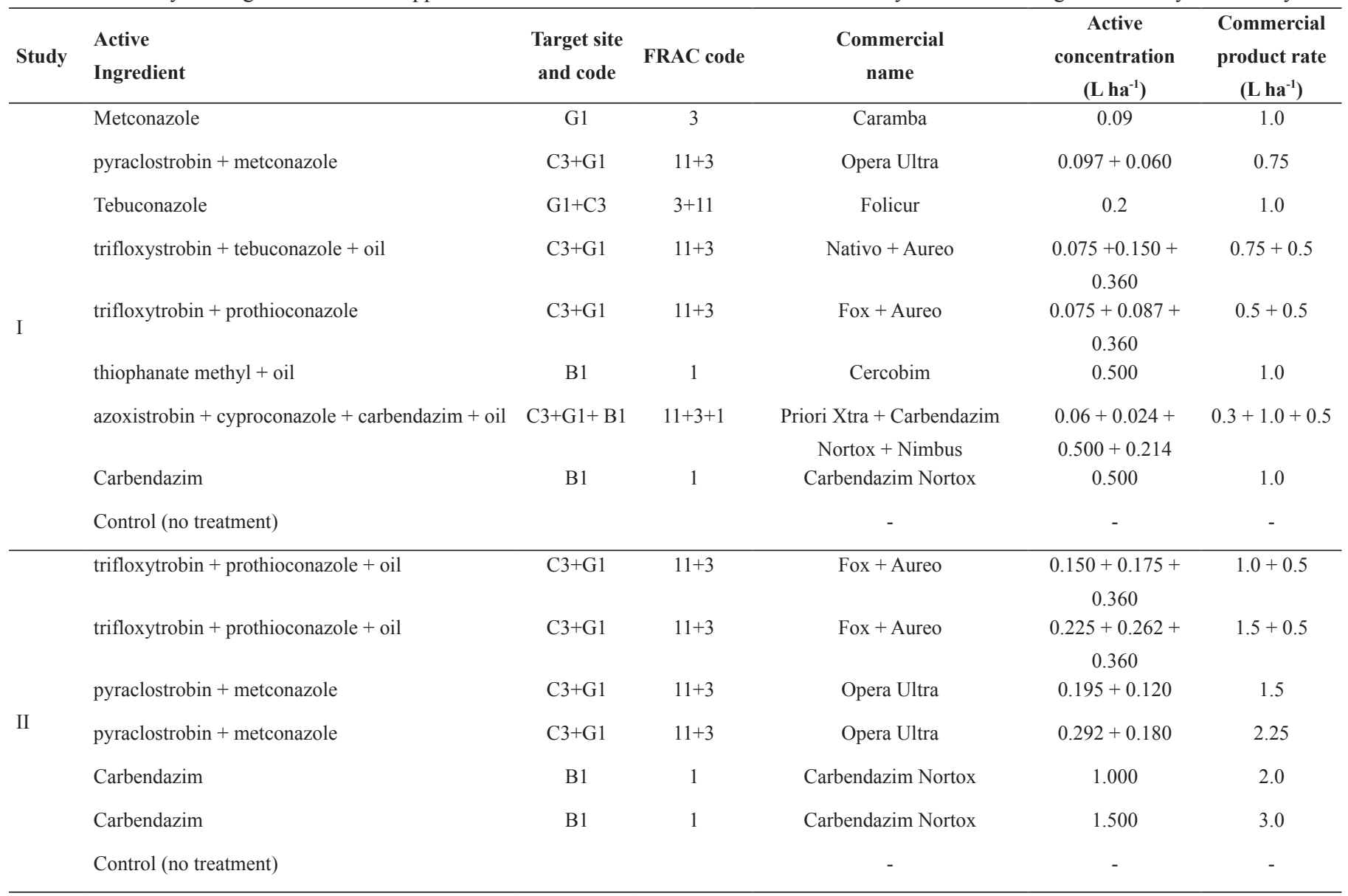

\section{Study II: Fungicide rates}

The different fungicide rates were assessed in a split-plot block design (Table 1). Fungicide application times (preventive and curative) and rates one and two times greater than those recommended for the cereal were allocated to the main plots and subplots, respectively. PR isolate of F. meridionale (MEMR0005) was the only isolate used in this experiment.

\section{Data analysis}

GER, GY and GD data underwent analysis of variance (ANOVA). The test for comparison of means was adopted when significance was reached according to Tukey's test $(\alpha=0.05)$. Statistical analysis was conducted by using PROC GLM in SAS, version 9.2 (SAS Institute Inc., Cary, NC)

\section{RESULTS AND DISCUSSION}

F. meridionale artificial inoculation in control plants showed no visible GER symptoms (data not shown), indicating that natural infection was absent. Therefore, the non-inoculated control treatment was not included in the statistical analysis.
Study I: Fungicides efficacy, grain yield and grain damage reduction

GER, GY and GD data showed homoscedasticity and were analyzed collectively in both 2014/15 and 2015/16 growing season. There was no significant difference for GER severity reduction among fungicides $(\mathrm{P}>0.05)$ despite the preventive and curative applications. Additionally, there was double significant interaction of $F$. meridionale isolates (MG and PR) versus application times.

Preventive application of mean fungicide rates to control MG isolate led to low GER severity (36.1\%), compared to curative application (47.7\%). GER severity caused by MG isolate was also low $(41.9 \%)$ for the mean fungicide rates and application times (preventive and curative), differing from PR isolate (48.1\%). Metconazole + pyraclostrobin, trifloxystrobin + prothioconazole, azoxystrobin + cyproconazole + carbendazim and carbendazim, preventively sprayed, and trifloxystrobin + prothioconazole and azoxystrobin + cyproconazole + carbendazim, curatively sprayed, reduced the mean GER severity caused by both MG and PR isolates, compared to the control treatment (Figures 1a and 1b). Trifloxystrobin + prothioconazole, preventively sprayed, reduced the mean GER severity caused by MG and PR isolates by $9 \%$ and $8 \%$, respectively, compared to control (Figure $1 \mathrm{a}$ and $1 \mathrm{~b}$ ).

GY was influenced by the interactions fungicides versus application times and application times versus F. meridionale isolates. Preventive and curative applications resulted in mean GY of $12.804 \mathrm{~kg} \mathrm{ha}^{-1}$ and 12.424 $\mathrm{kg} \mathrm{ha}^{-1}$, respectively, considering the mean fungicide rates to control MG isolate (Figure 1c). There was a significant difference in GY among 
curatively applied fungicides for PR isolate (Figure 1d). Metconazole + pyraclostrobin, tebuconazole + trifloxystrobin, trifloxystrobin + prothioconazole, thiophanate-methyl and tebuconazole showed a superior increment, compared to the control treatment (Figure 1d).

GD incidence was not influenced by fungicide application (Figure $2 \mathrm{a}$ and $2 \mathrm{~b}$ ). The high percentage of GD (5\% moldy, $26 \%$ fermented and $13 \%$ rotten grains), considering the mean fungicide rates and application times, was caused by PR isolate, compared to MG isolate (3\% moldy, $22 \%$ fermented and $9 \%$ rotten grain) (Figure $2 \mathrm{c}$ ). Trifloxystrobin + prothioconazole, azoxystrobin + cyproconazole + carbendazim and carbendazim were the only fungicides that reduced GD incidence caused by both MG and PR isolates, compared to control treatment (Figure 2a and 2b). Preventive application of a mixture of triazoles with strobirulin and carbendazim reduced mean GD caused by both MG and PR isolates, compared to azoxystrobin + cyproconazole + carbendazim and carbendazim in curative applications (Figure 2a, 2b and 2c).

\section{Study II: Fungicide rates}

Increasing fungicide rates and the application times influenced mean GER severity, GY and GD incidence at the three different sowing dates (Figure 3). Curative and preventive application reduced mean GER severity by $37 \%$ and $26 \%$, respectively, considering application times at the three different sowing dates, rates and fungicides.

All preventively applied fungicides, except carbendazim $(1.5 \mathrm{~L}$ $\mathrm{ha}^{-1}$ ), led to a significant reduction in mean GER severity, compared to the control treatment at the different sowing dates. Pyraclostrobin + metconazole $\left(0.19+0.12 \mathrm{~L} \mathrm{ha}^{-1}\right)$, preventively and curatively applied, showed mean GER severity of $25.5 \%$ and $37.5 \%$, respectively, compared to that of the control treatment: $46 \%$ (Figure 3a, 3b and $3 c)$. Trifloxystrobin + prothioconazole $(0.15+0.17$ and $0.22+0.26 \mathrm{~L}$ $\left.\mathrm{ha}^{-1}\right)$ and pyraclostrobin + metconazole $(0.19+0.12$ and $0.29+0.18$ $\mathrm{L} \mathrm{ha}^{-1}$ ), curatively applied, showed GER severity that was low but not statistically different from that of control (Figure $3 a, 3 b$ and $3 c$ ).

There was a significant interaction of fungicides versus application times for GY. Preventive application of trifloxystrobin + prothioconazole $\left(0.15+0.17\right.$ and $\left.0.22+0.26 \mathrm{~L} \mathrm{ha}^{-1}\right)$ increased mean GY by $45.7 \%$ (3.337 $\left.\mathrm{kg} \mathrm{ha}^{-1}\right)$ and 54.1\% (3.952 $\left.\mathrm{kg} \mathrm{ha}^{-1}\right)$, respectively, considering the mean yield for each treatment (rates), compared to control. There was an increment of $35.6 \%\left(2.596 \mathrm{~kg} \mathrm{ha}^{-1}\right)$ in mean GY when trifloxystrobin + prothioconazole $\left(0.225+0.262 \mathrm{~L} \mathrm{ha}^{-1}\right)(2.596$
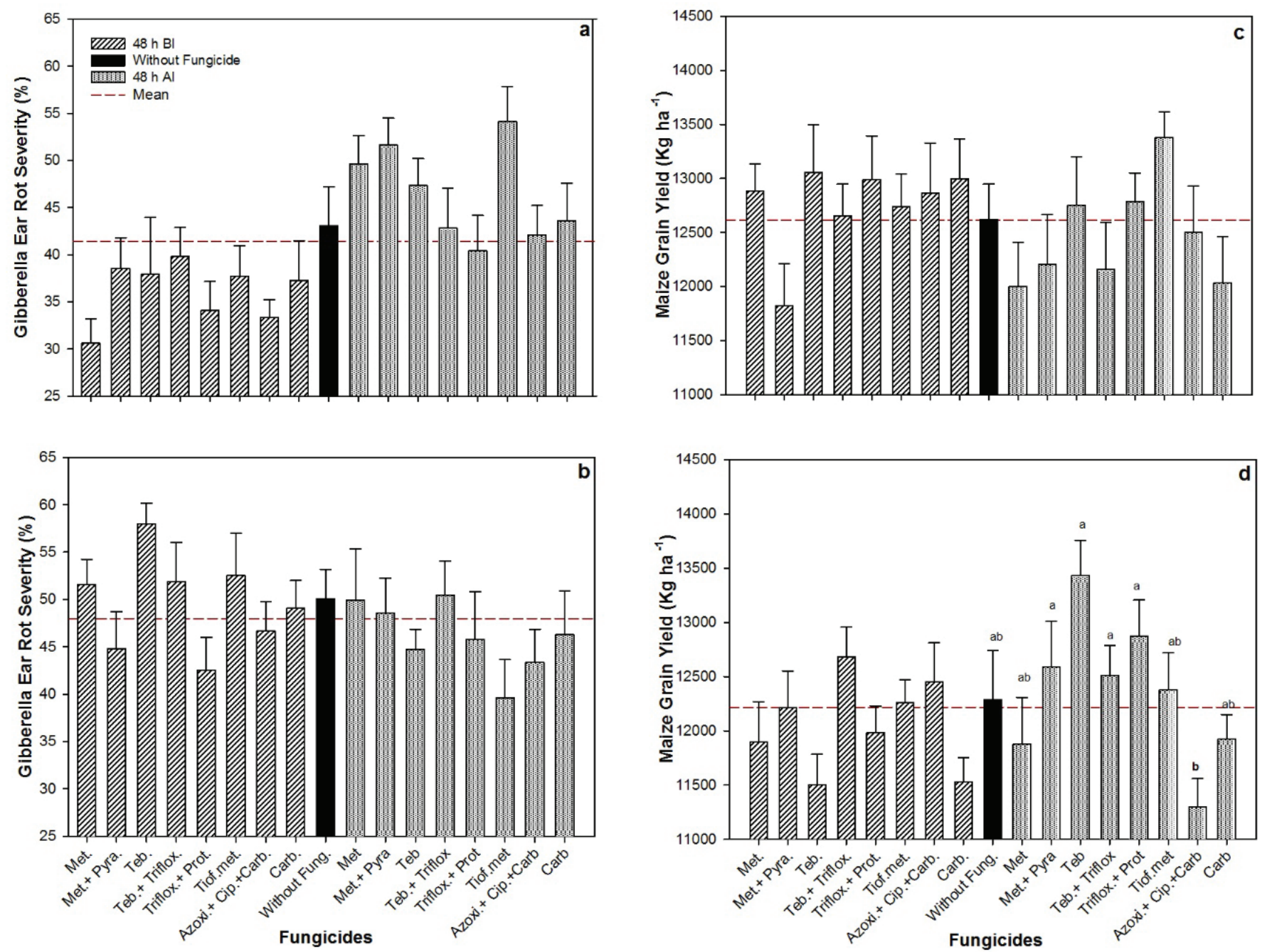

Figure 1. Gibberella ear rot severity (GER) (\%) after inoculation of isolates from Minas Gerais State (a) and Paraná State (b), and maize grain yield (GY) (c, d) when plants were inoculated with a spore suspension of Fusarium meridionale and subjected to preventive (48 hours before inoculation- BI) or curative fungicide application (48 hours after inoculation- AI). Lages County, Santa Catarina State, Brazil. 

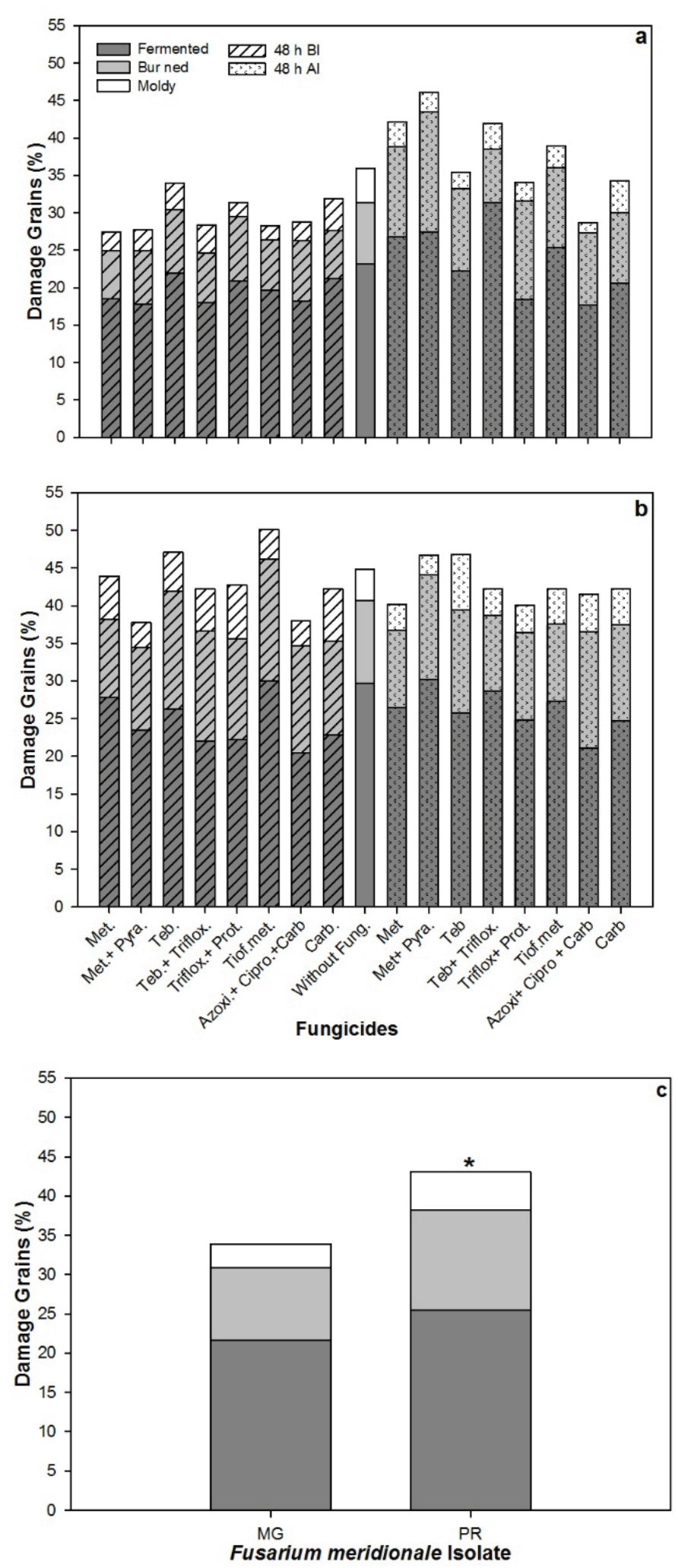

Figure 2. Summary of the mean percentage of maize grain damage (GD) after inoculation of isolates from Minas Gerais State (a) and Paraná State (b), and mean percentage of (GD) (c) when plants were artificially inoculated with the two Fusarium meridionale isolates and subjected to preventive (48 hours before inoculation-BI) or curative fungicide application (48 hours after inoculation- AI). Lages County, Santa Catarina State, Brazil. $\mathrm{kg} \mathrm{ha}^{-1}$ ) were curatively applied, compared to the control treatment (Figure 3d, 3e and 3f).

Mean GD incidence was lower for the two fungicides rates (one and two times the cereal recommended rates) and application times (preventive and curative), compared to the control treatment in all three experiments (Figure 3g, 3h and 3i). There was a significant difference among the three fungicides applied at the two different rates, compared to control. Mean GD reduction was higher than $50 \%$ for the mean fungicide rates preventively applied, compared to the control treatment. There was no significant difference between fungicides and rates compared to the control treatment despite the $35 \%$ reduction in mean GD (Figure $3 \mathrm{~g}, 3 \mathrm{~h}$ and 3i).

Preventive fungicide application showed high reduction in GER severity, compared to the curative application. Since the inoculations were performed after silk emergence, the active ingredient of fungicides could reach the young stigma, which is closer to the peak of silk susceptibility to FHB $(6,10,21,24)$. Fungicide applications around this time could improve the coverage of susceptible tissues, reducing both fungal infection and colonization. This is reasonable because susceptibility in wheat is greatest at anthesis, which is regarded as the optimal growth stage for fungicide applications to control FHB (5, 18, 22, 24). According to Andriolli et al. (1), fungicide application $48 \mathrm{~h}$ before or after $F$. meridionale inoculation, at maize flowering, showed low GER severity, compared to the fungicide application at 96 and $144 \mathrm{~h}$ after $F$. meridionale inoculation. Preventive application of trifloxystrobin + prothioconazole and azoxystrobin + cyproconazole + carbendazim (Figure 1a and 1b) showed low GER severity, corroborating the data found by Andriolli et al. (1), who used the second fungicide mixture and rates. In their studies with Fusarium proliferatum infected maize, Pusztahelyi et al. (20) concluded that the treatment with prothioconazole and tebuconazole was suitable when done before flowering, while azoxystrobin-propiconazole treatments were equally successful before and after maize flowering, considering the decreasing fumonisin concentration of kernels. Trifloxystrobin + prothioconazole $(0.15+$ 0.17 and $\left.0.22+0.26 \mathrm{~L} \mathrm{ha}^{-1}\right)$, pyraclostrobin + metconazole $(0.19+$ 0.12 and $\left.0.29+0.18 \mathrm{~L} \mathrm{ha}^{-1}\right)$ and carbendazim $\left(1.0 \mathrm{~L} \mathrm{ha}^{-1}\right)$, applied at increasing rates, showed efficiency despite the preventive and/or curative spraying. Prothioconazole is indicated to control Gibberella ear rot in different regions of the US and Canada, at $0.171 \mathrm{~L}$ active ingredient (a.i ha ${ }^{-1}$ ), sprayed between R1 (silking) and R2 (blister) stage $(2,8)$. Prothioconazole is found in Brazil in mixture with trifloxystrobin (Fox ${ }^{\circledR}$ ) at 0.087 and $0.075 \mathrm{~L}$ i.a ha ${ }^{-1}$, respectively (3). Prothioconazole applied at commercial (trade name) rate did not satisfactorily control GER, compared to the control treatment (Figure 1a and 1b). However, when prothioconazole and trifloxystrobin were applied at increasing rates of 0.175 and $0.262 \mathrm{~L} \mathrm{ha}^{-1}$ and 0.150 and $0.225 \mathrm{~L} \mathrm{ha}^{-1}$, respectively, there was a significant reduction of $41 \%$ and $50 \%$ in GER incidence and an increasing GY of $3.337 \mathrm{~kg} \mathrm{ha}^{-1}(45 \%)$ and $3.418 \mathrm{~kg} \mathrm{ha}^{-1}(45 \%)$, respectively, compared to the control treatment (Figure 3). These data demonstrated that preventive application reduced GER incidence by $6.3 \%$ and $5.3 \%$ for both fungicide efficacy and fungicide rate studies, compared to curative application. Additionally, preventive application and increasing rates during the maize ear stigma emission showed a significant increase in GY, compared to the curative application.

The present results lead to the conclusion that there was a variation in fungicide efficacy according to $F$. meridionale isolates and fungicide application times. The increasing fungicide rates of some specific active ingredients preventively applied for Fusarium control can reduce GER and GD incidence and increase GY, especially when the fungicides were applied at the beginning of silk stage. 

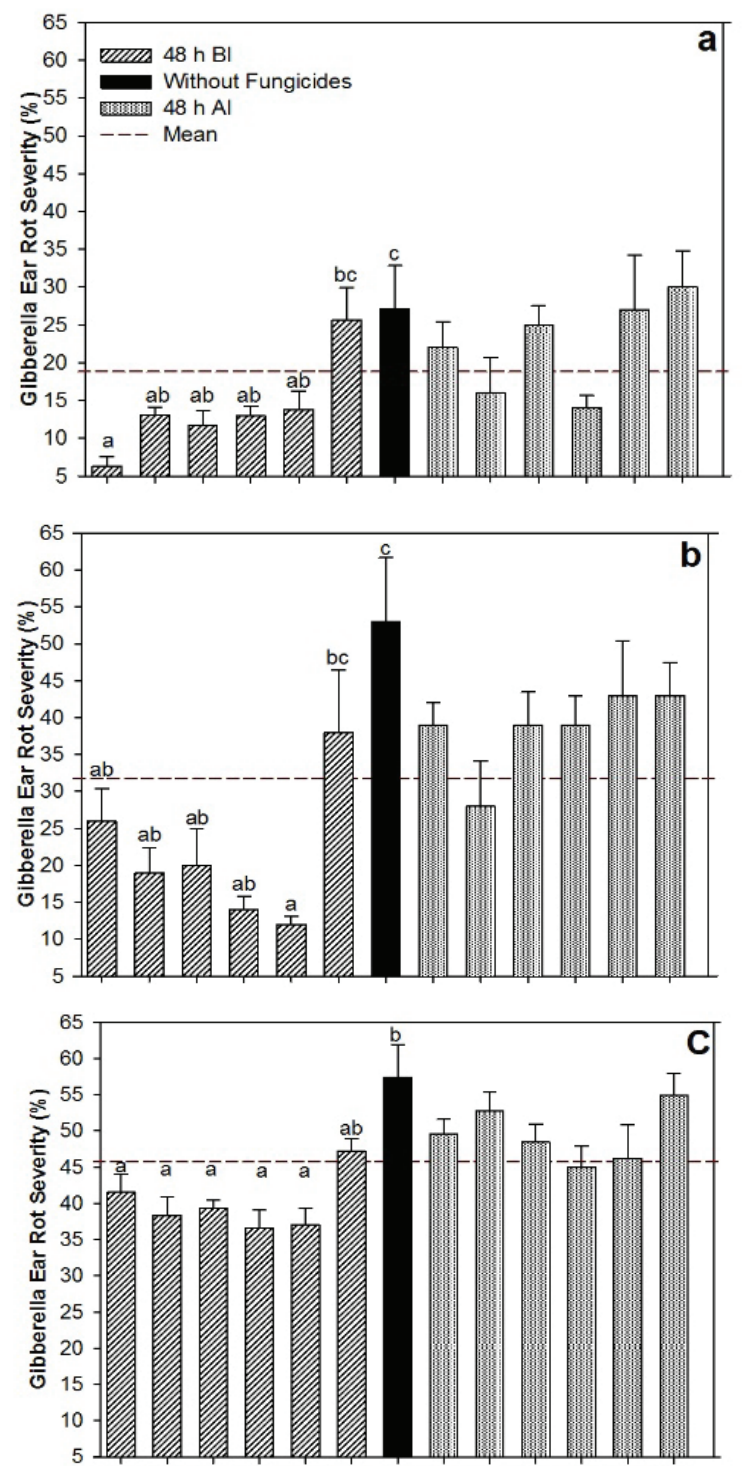

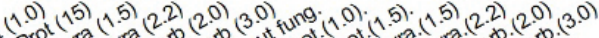
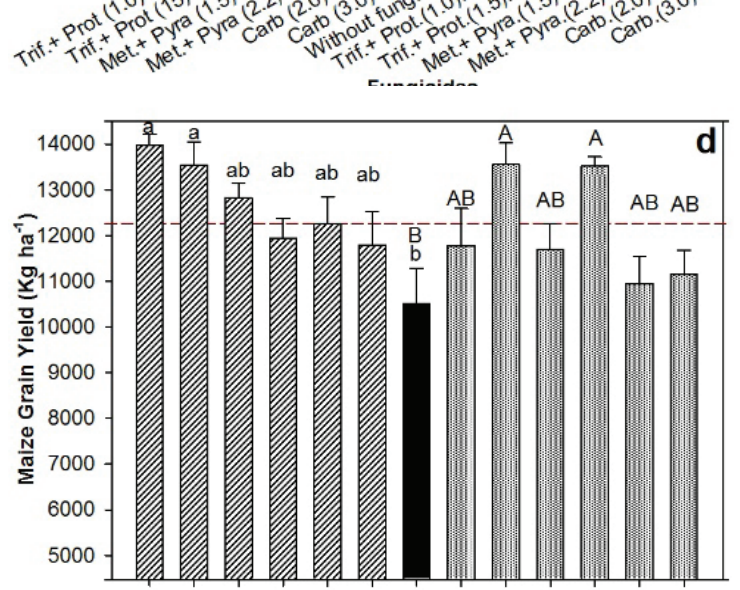

Figure 3. Mean percentage of Gibberella ear rot severity (a, b, c), maize grain yield $(\mathrm{d}, \mathrm{e}, \mathrm{f})$ and mean percentage of maize grain damage $(\mathrm{g}, \mathrm{h}, \mathrm{i})$ when plants were artificially inoculated with Fusarium meridionale and subjected to preventive (48 hours before inoculation- $\mathrm{BI}$ ) or curative fungicide application (48 hours after inoculation- AI), in three environments, during the 2014/15 (a, d, g) and 2015/16 (b, c, e, f, h, i) growing seasons. Lages County, Santa Catarina State, Brazil.
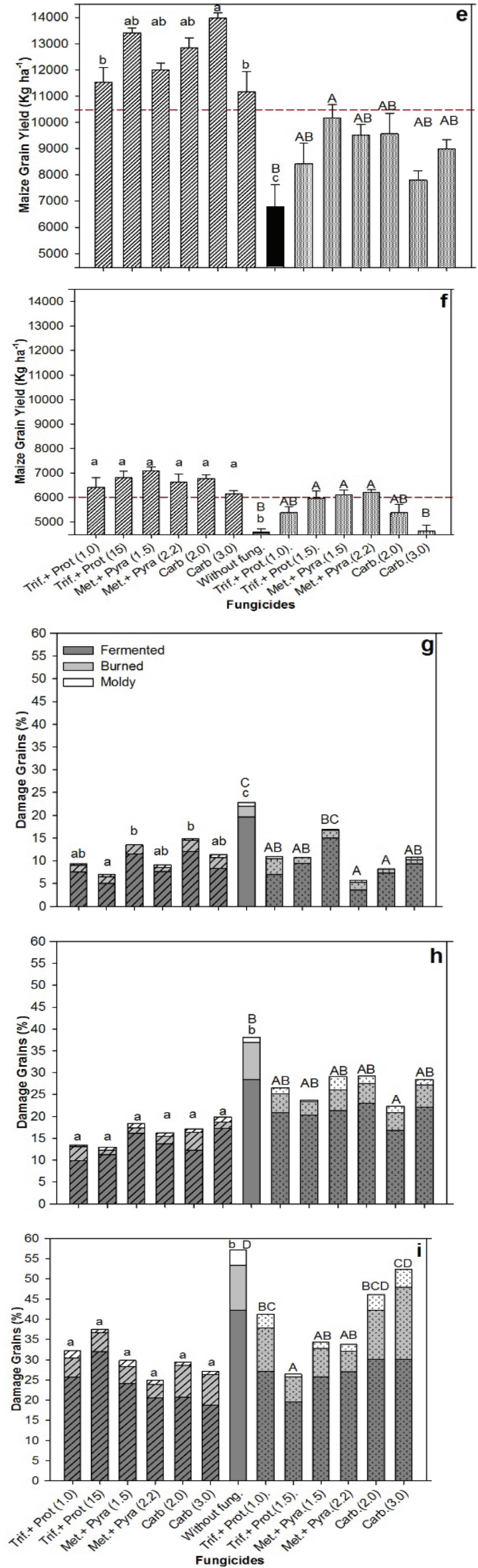

Summa Phytopathol., Botucatu, v. 45, n. 3, p. 265-271, 2019 


\section{ACKNOWLEDMENTS}

This study was financially supported by UDESC (Santa Catarina State University), CNPq (The National Council for Scientific and Technological Development) and CAPES (Coordination for the Improvement of Higher Level -or Education- Personnel).

\section{REFERENCES}

01. Andriolli, C.F.; Casa, R.T.; Kuhnem R.P.; Bogo, A.; Zancan, R.L.; Reis, M.R. Timing of fungicide application for the control of Gibberella ear rot of maize. Tropical Plant Pathology, Viçosa, v.41, p.264-269, 2016.

02. Bayer Crop Science. Proline 480 SC Fungicide. North Carolina, 2016. Available in: <https://s3-us-west1.amazonaws.com/www.agrian.com/pdfs/ Proline_480_SC1h_Fungicide_Label.pdf $>$ Accessed in: 06 fev. 2018.

03. Bayer Crop Science. FOX. São Paulo, 2017. Available in: <http://www. cropscience.bayer.com.br/site/bulas/FOX.pdf $>$. Accessed in: 13. jun. 2017

04. Brito, A.H.; Pereira, J.L.A.R.; Pinho, R.G.V.; Balestre, M. Controle químico de doenças foliares e grãos ardidos em milho (Zea mays L.). Revista Brasileira de Milho e Sorgo, Sete Lagoas, v.11, n.1, p.49-59, 2012.

05. Casa, R.T.; Bogo A.; Moreira E.N.; Kuhnem, P.R.J. Época de aplicação e desempenho de fungicidas no controle da giberela em trigo. Ciência Rural, Santa Maria, v.37, n.6, p.1558-1563, 2007.

06. Chungu C.; Mather, D.E.; Reid, L.M; Hamilton, R.I. Comparison of techh niques for inoculating maize silk, kernel, and cob tissues with Fusarium graminearum. Plant Disease, St. Paul, v.80, n.1, p.81-84, 1996.

07. Cunha, J.P.A.R.; Silva, L.L.; Boller, W.; Rodrigues, F.J. Aplicação aérea e terrestre de fungicida para o controle de doenças do milho. Revista Ciência Agronômica, Fortaleza, v.41 n.3, p.366-372, 2010.

08. Dragich, M.; Nelson, S. Gibberella and Fusarium ear rot of maize in Hawaii. Plant Disease, St. Paul, v.98, p.1-8, 2014

09. Juliatti, F.C.; Zuza, J.L.M.F.; Souza, P.P.; Polizel, A.C. Efeito do genótipo de milho e da aplicação foliar de fungicidas na incidência de grãos ardidos. Bioscience Journal, Uberlândia, v.23, n.2, p.34-41, 2007.

10. Kuhnem Júnior, P.R. Stumpf, R.; Spolti, P.; Del Ponte, E.M. Características patogênicas de isolados do complexo Fusarium graminearum e de Fusarium verticillioides em sementes e plântulas de milho. Ciência Rural, Santa Maria, v.43, n.4, p.583-588, 2013

11. Kuhnem, P.R.; Ward, T.J.; Silva, C.N.; Spolti, P.; Ciliato, M.L.; Tessmann, D.J.; Del Ponte, E.M. Composition and toxigenic potential of the Fusarium graminearum species complex from maize ears, stalks and stubble in Brazil. Plant Pathology, San Diego, v.65, n.7, p.1185-1191, 2016.

12. Landschoot, S.; Audenaert, K.; Waegeman, W.; De Baets, B.; Haesaert, G. Influence of maize-wheat rotation systems on Fusarium head blight infection and deoxynivalenol content in wheat under low versus high disease pressure. Crop Protection, Oxford, v.52, p.14-21, 2013.
13. Ministério da Agricultura, Pecuária e Abastecimento. Instrução Normativa $\mathrm{n}^{\circ}$ 60, de 22 de dezembro de 2011. Diário Oficial da União, Brasília, DF, 23 dez. 2011. Seção 1. Available in: <http://sistemasweb.agricultura.gov. br/sislegis/action/detalhaAto.do?method=visualizarAtoPortalMapa\&cha$\mathrm{ve}=1739574738>$. Accessed in: 16 jun. 2017.

14. Munkvold, G.P. Epidemiology of Fusarium diseases and their mycotoxins in maize ears. European Journal of Plant Pathology, Dordrecht, v.109, n.7, p.705-713, 2003.

15. Munkvold, G.P.; Desjardins, A.E. Fumonisins in maize: can we reduce their occurrence? Plant Disease, St. Paul, v.81, n.6, p.556-565, 1997.

16. Nerbass, F.R.; Casa, R.T.; Kunhnem, P.R.; Vieira, J.A.L.J.; Valente, J.B. Field evaluation of maize for Gibberella ear rot resistance using silk channel and kernel inoculation with Fusarium meridionale. Tropical Plant Pathology, Brasília, DF, v.40, n.6, p.388-393, 2015.

17. Nerbass, F.R. Casa, R.T.; Kunhnem, P.R.; Bogo, A.; Sangoi, L.; Fingstag, M.D.; Vieira, J.A.L.J.; Stoltz, J.C. Evaluation of Fusarium graminearum inoculation methods in maize ears and hybrid reaction to Gibberella ear rot under southern Brazilian environmental conditions. European Journal of Plant Pathology, Dordrecht, v.144, n.1, p.45-53, 2016.

18. Paul, P.A.; Lipps, P.E.; Hershman, D.E.; McMullen, M.P.; Draper, M.A. Madden, L.V. A quantitative review of tebuconazole effect on Fusarium head blight and deoxynivalenol content in wheat. Phytopathology, St. Paul, v.97, n.2, p.211-220, 2007

19. Pinto, N.F.J.D.A. Controle químico de doenças foliares em milho. Revista Brasileira de Milho e Sorgo, Sete Lagoas, v.3, n.1, p.134-138, 2004.

20. Pusztahelyi, T.; Radócz, L.; Gellért, C.; Kovács, S.; Szabó, Z.; Pócsi, I,; Vad, A. Effect of preventive and curative fungicide treatment on Fusarium proliferatum infected maize - a field trial. Acta Phytopathologica et Entomologica Hungarica, Hungary, v.52, n.1, p.29-38, 2017.

21. Reid, L.M.; Hamilton, R.I. Effects of inoculation position, timing, macroconidial concentration, and irrigation on resistance of maize to Fusarium graminearum infection through kernels. Canadian Journal Plant Pathology, Ottawa, v.18, p.279-285, 1996.

22. Reis, E.M.; Blum, M.M.C.; Casa, R.C. Controle químico de Gibberella zeae em trigo um problema de deposição de fungicidas em anteras. Summa Phytopathologica, Botucatu, v.22, n.3/4, p.39-42, 1996.

23. Reis, E.M.; Casa, R.C.; Bianchin, V. Controle de doenças de plantas pela rotação de culturas. Summa Phytopathologica, Botucatu, v.37, n.3, p.8591, 2011.

24. Spolti, P.; Guerra, D.S; Badiale-Furlong, E.; Del Ponte, E.M. Single and sequential applications of metconazole alone or in mixture with pyraclostrobin to improve Fusarium head blight control and wheat yield in Brazil. Tropical Plant Pathology, Viçosa, v.38, n.2, p.85-96, 2013.

25. Sutton, J.C. Epidemiology of wheat head blight and maize ear rot caused by Fusarium graminearum. Canadian Journal Plant Pathology, Ottawa, v.4, p.195-209, 1982.

26. Stumpf, R.; dos Santos, J.; Gomes, L.B.; Silva, C.N.; Tessmann, F.D.; Ferreira, F.D.; Machinski Junior, M.; Del Ponte, E.M. Fusarium species and fumonisins associated with maize kernels produced in Rio Grande do Sul State for the 2008/09 and 2009/10 growing seasons. Brazilian Journal Microbiology, São Paulo, v.44, n.1, p.89-95, 2013. 